\title{
Modul Deteksi dan Perekaman Data Gempa berbasis Database Earthquake Intensity (DEI)
}

\section{IRNANDA PRIYADI' ${ }^{1}$, FAISAL HADI ${ }^{2}$, SALWA KHOTIMAH ${ }^{3}$, BESPERI $^{4}$}

\author{
1,2,3Teknik Elektro Universitas Bengkulu, Indonesia \\ ${ }^{4}$ Teknik Sipil Universitas Bengkulu, Indonesia \\ Email: Irnanda_P@unib.ac.id
}

Received 28 Februari 2021 | Revised 24 Maret 2021 | Accepted 15 April 2021

\begin{abstract}
ABSTRAK
Indonesia, khususnya provinsi Bengkulu, adalah salah satu negara yang rawan bencana gempa. Hal ini disebabkan karena secara histografi, posisi wilayah Indonesia merupakan pertemuan tiga lempeng aktif yang setiap kali lempeng ini bergeser menimbulkan patahan yang menyebabkan terjadinya gempa bumi. Paper ini membahas tentang rancangan modul deteksi gempa yang diberi nama Earthquake Intensity Meter. Rancangan modul terdiri dari sensor MEMS MPU6050 dan 2 buah sensor piezoelektrik. Masing-masing sensor dipisahkan dengan jarak 10 meter dengan sensor MPU6050 yang menjadi pusatnya dan 2 sensor piezoelektrik hanya sebagai pemicu. Kombinasi sensor MPU6050 dan 2 sensor piezoelektrik mampu digunakan untuk membedakan getaran gempa dan bukan gempa dengan tingkat keberhasilan 32\%. Aplikasi Vibrometer yang digunakan sebagai media kalibrasi, memiliki selisih 17\% dengan intensity meter. Sedangkan akurasi sensor MPU6050 dalam rancangan modul memiliki selisih 11,17\% dengan aplikasi vibrometer. Data hasil pendeteksian rancangan divisualisasikan secara realtime dan disimpan pada aplikasi DEI yang dirancang dengan VB 2010.
\end{abstract}

Kata kunci: deteksi gempa, mpu6050, piezoelektrik, vibrometer, VB 2010

\begin{abstract}
Indonesia, especially Bengkulu province, is one of the countries prone to earthquake disasters. This is because histographically, the position of the Indonesian territory is a junction of three active plates which each time these plates shift, causing fractures that cause earthquakes. This paper discusses the design of an earthquake detection module called the Earthquake Intensity Meter. The module design consists of a MEMS MPU6050 sensor and 2 piezoelectric sensors. Each sensor is separated by a distance of 10 meters with the MPU6050 sensor at the center and 2 piezoelectric sensors only as a trigger. The combination of the MPU6050 sensor and 2 piezoelectric sensors can be used to distinguish between earthquake and non-earthquake vibrations with a $32 \%$ success rate. The Vibrometer application, which is used as a calibration medium, has a difference of $17 \%$ with an intensity meter. Meanwhile, the accuracy of the MPU6050 sensor in the module design has a difference of $11,17 \%$ with the vibrometer application. Data from design detection results is visualized in real time and stored in the DEI application designed with VB 2010.
\end{abstract}

Keywords: earthquake detector, mpu6050, piezoelectric, vibrometer, VB 2010 


\section{PENDAHULUAN}

Indonesia merupakan negara yang terletak di pertemuan tiga lempeng tektonik dunia yakni lempeng Pasifik, Eurasia, dan Indo-Australia. Hal ini menjadikan sebagian besar daerah di Indonesia sering mengalami gempa bumi. BMKG mencatat sejak awal tahun 2021 hingga 18 Februari 2021 terjadi 30 kali gempa bumi dengan magnitudo lebih dari 5 SR. Tujuh kali diantaranya terjadi di Provinsi Bengkulu (BMKG, 2021). Indonesia sebagai negara yang cukup luas hanya memiliki 194 seismograf yang disebar di seluruh penjuru negeri. Kepala Badan Meteorologi Klimatologi dan Geofisika (BMKG), Dwikorita Karnawati memastikan pihaknya akan menambah 194 alat sensor pendeteksi gempa, seismograf untuk mengantisipasi dan mengukur guncangan akibat gempa bumi di seluruh Indonesia. Dengan penambahan ini, maka keseluruhan sensor yang dimiliki BMKG nantinya akan berjumlah 400 buah (Putra, 2019). Seismograf analog yang menggunakan pena dan drum membuat analisa gelombang gempa tidak dapat dilakukan dengan real time. Selain itu, seismograf analog menghasilkan seismogram berbentuk kertas memerlukan perlakuan khusus dalam penyimpanannya. Saat ini sudah hadir seismograf digital yang analisa datanya dapat dilakukan secara lebih cepat dan mudah. Namun harga seismograf masih relatif tinggi. Alat pendeteksi gempa bumi adalah peralatan yang komplek dan mahal (Wang, 2016). Disisi lain seismograf digital yang digunakan BMKG saat ini memiliki ukuran yang besar dengan konstruksi yang rumit. Data yang dihasilkan juga masih berupa data mentah yang harus diolah lebih lanjut oleh perangkat yang terpisah. Penelitian ini bertujuan menghadirkan alat pengukur intensitas gempa dengan konstruksi yang sederhana dengan data yang lebih mudah dianalisa dan harganya murah menggunakan sensor akselerometer berbasis MEMS dengan ukuran sekecil mungkin dan memiliki akurasi tinggi. Kedepan modul ini diharapkan bisa menjadi alternatif referensi bagi masyarakat terutama para peneliti dalam merancang modul deteksi bencana gempa.

Pada penelitian sebelumnya yang dilakukan oleh Yoga Priyana dkk, digunakan sensor akselerometer tipe ADXL335 dalam mendeteksi P-wave. Sensor tersebut mampu mendeteksi gempa mulai dari getaran terkecil hingga geratan yang paling dahsyat. Skala gempa yang digunakan adalah MMI scale. Skala MMI memiliki nilai intensitas mulai yang terrendah bernilai 1 hingga yang tertinggi bernilai (Priyana, 2017). Adapun penelilitian yang dilakukan oleh Padma Nyoman dkk, digunakan sensor MPU6050 sebagai pendeteksi getaran gempa. Hasil pendeteksian akselerasi sensor dikonversi ke dalam Skala Intensitas Gempa bumi BMKG (SIG BMKG) (Crisnapati, 2019). Selanjutnya penelitian yang menghubungkan magnitudo gempa bumi dengan percepatan dilakukan oleh Rahinul menggunakan sensor ADXL345 untuk mendeteksi gempa bumi (Hoque, 2016). Penerapan jaringan wireless sensor di daerah rawan gempa dan penerapan ICT (Information Communication and Technology) terbukti sangat membantu dalam menghindari situasi yang menghancurkan saat terjadinya gempa dan melindungi banyak orang dari kerugian besar (Rahman, 2016). Pada penelitian ini, modul deteksi gempa yang dirancang menggunakan sensor MEMS yang berukuran sangat kecil, komunikasi datanya menggunakan I2C sehingga tidak memungkinkan dilakukan pengukuran keluaran berupa tegangan, daya, dan arus. Pengujian performa modul dilakukan menggunakan simulasi gempa dengan sistem monitoring hasil pembacaan sensor deteksi gempa tetapi tidak membahas spesifik tentang sistem penentuan episentrum gempa. Hasil pembacaan sensor ini akan tersimpan dalam database sistem aplikasi DEI yang dirancang untuk selanjutnya dapat digunakan dalam studi kegempaan. 


\section{METODE}

\subsection{Gambaran Rancangan Modul}

Teknologi Internet of Things (IoT) telah diimplementasikan untuk memberikan solusi terkait deteksi kejadian tertentu karena kemudahan instalasi, kemampuan komputasi dan komunikasi, serta efektivitas biaya. Namun deteksi kejadian seismik seperti gempa masih menjadi tantangan karena kurangnya penginderaan dengan ketepatan tinggi dan efisiensi (Won, 2020). Sebuah aplikasi yang mengukur gempa bumi menggunakan sensor akselerasi MEMS sedang dikembangkan di terminal informasi smartphone yang menerima, menyimpan, dan menampilkan catatan seismik di server cloud (Naito, 2013). Teknologi sistem elektromekanik (MEMS) berkembang pesat hampir setiap tahun dalam penggunaan elektronik. Sensor-sensor berbasis MEMS menjadi elemen penting dalam rancangan produk yang berbeda untuk pasar konsumen pengguna sistem cerdas. MEMS memberikan cara baru untuk berinteraksi dengan perangkat pintar teknologi lainnya, diantaranya gyroscope (sensor gempa) (Dadafshar, 2014).

Sensor seismik digunakan untuk mendeteksi dan mengukur getaran gelombang gempa. Sensor akseleromter 3 axis digunakan sebagai bagian utama dari sensor seismik, untuk dapat mengukur getaran gempa 3 sumbu berdasarkan perubahan nilai gravitasi yang diukur untuk setiap sumbu. Teknologi MEMS (sistem elektro-mekanis mikro) diterapkan pada accelerometer untuk mengukur percepatan pergerakan bumi yang terjadi di setiap sumbu ( $\mathrm{x}$, $y, z)$ dan dapat diterapkan pada mitigasi bahaya gempa (Novianta, 2014). Beberapa jenis sensor akselerometer berbasis MEMS telah dikembangkan dan digunakan secara luas dalam menyebarkan jaringan seismik berskala besar untuk sistem peringatan dini bencana gempa (Earthquake Early Warning System) (Peng, 2017).

Sensor acceleromoter cocok digunakan pada aplikasi portabel dan sangat mudah digunakan pada rangkaian mikrokontroler semacam papan pengembang Arduino. Hal ini karena akses data yang dilakukan dengan mudah melalui antarmuka I2C. GY-521 adalah sebuah modul Inertial Measurement Unit (IMU) yang menggunakan chip MPU-6050 dari InvenSense. MPU6050 adalah chip dengan 3-axis accelerometer (sensor percepatan) dan 3-axis gyroscope (pengatur keseimbangan), atau dengan kata lain 6 degrees of freedom (DOF) IMU. Selain itu, MPU- 6050 sudah memiliki Digital Motion Processors (DMP), yang akan mengolah data mentah dari masing- masing sensor. Sejumlah data tersebut akan diolah menjadi data dalam bentuk quaternions (4 dimensi). DMP pada MPU6050 juga berfungsi meminimalisasi error yang dihasilkan. Sensor GY-521 memiliki range pengukuran akselerasi mulai dari $2 \mathrm{~g}, 4 \mathrm{~g}, 8 \mathrm{~g}$, dan $16 \mathrm{~g}$. Masing masing range mempunyai alamatnya masing-masing, hal ini dikarenakan sensor ini menggunakan I2C sebagai antar mukanya (Firman, 2016). Modul deteksi gempa yang dirancang berupaya meminimalkan biaya sensor yang menjadi masalah penting dalam membangun sistem peringatan dini gempa (Fu, 2019).

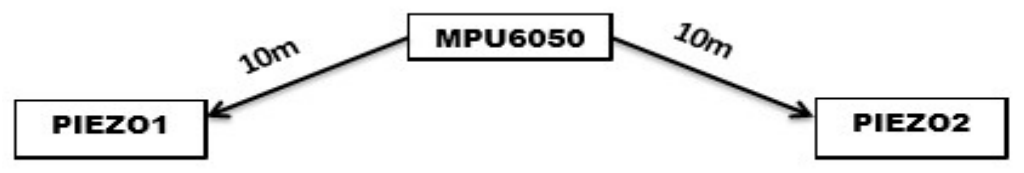

Gambar 1. Cara Kerja Sistem

Rancangan modul sistem pendeteksi gempa secara singkat ditunjukkan pada Gambar 1 dan Gambar 2. Gambar 1 menunjukkan bahwa cara kerja modul menggunakan tiga buah sensor dalam mendeteksi getaran gempa bumi. Sensor utama yang digunakan adalah jenis MEMS dengan tipe MPU6050, dimana terdapat sensor akselerometer dan giroskop didalamnya. 
Namun yang digunakan untuk mendeteksi gempa hanya sensor akselerometernya saja. Selain itu digunakan dua buah sensor piezoelektrik yang dihubungkan dengan kabel yang panjangnya sekitar 10 meter. Tujuan digunakannya kabel yang panjangnya sekitar 10 meter ini adalah untuk memaksimalkan jarak antar sensor. Dengan meletakkan sensor dengan jarak yang jauh, sistem akan mendeteksi getaran dalam jangkauan yang lebih luas.

Gambar 2 menunjukkan peralatan yang digunakan dan koneksinya ke Arduino. Sensor akselerometer MPU6050 dan piezoelektrik berfungsi sebagai pendeteksi getaran gempa bumi, RTC berfungsi untuk memberi waktu untuk setiap data yang diperoleh secara real time yang disimpan pada SD card. LCD berfungsi menampilkan data yang diperoleh. Sedangkan terminal Block untuk mempermudah melakukan bongkar pasang komponen. Tiga buah modul (MPU6050, LCD, dan RTC) dihubungkan ke Arduino melalui perantara antarmuka I2C pada pin yang sama, yakni pin data dan pin clock. Meski terhubung ke pin yang sama, dalam pemrogramannya masing-masing komponen memiliki alamatnya sendiri untuk dapat bekerja. Alamat I2C sensor MPU6050 adalah 0x69, RTC 0x68, dan LCD 0x27. Selanjutnya, untuk mengurangi error, maka sampling rate yang digunakan pada arduino menggunakan kecepatan standar 9600 bps.

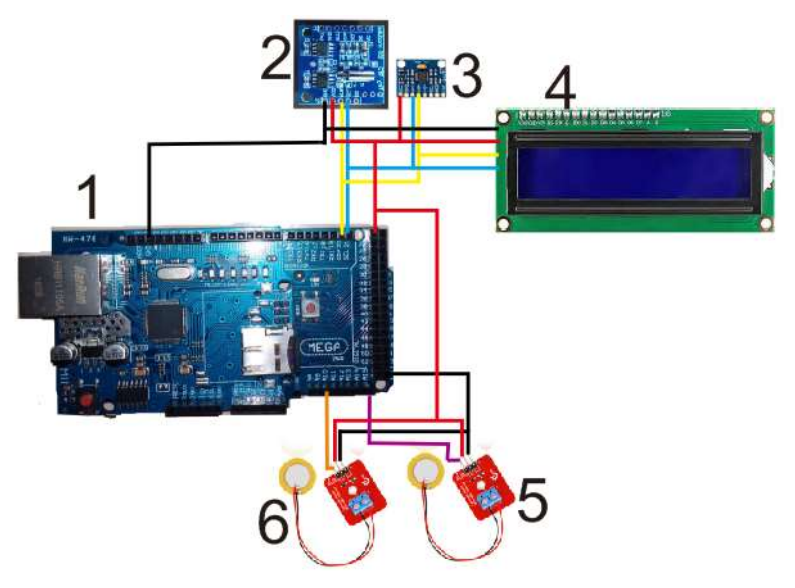

\section{Gambar 2. Rangkaian Earthquake Intensity Meter}

Keterangan Gambar 2 :

1. Arduino Mega dan Modul Sdcard shield

2. RTC

4. LCD $16 \times 2$

3. MPU6050

5. Terminal Block

6. Sensor Piezoelektrik

\subsection{Rancangan Aplikasi DEI}

Alat yang dirancang akan dimonitoring secara realtime dengan aplikasi DEI (Database Earthquake Intensity) yang dirancang menggunakan Visual Basic 2010. Antarnuka aplikasi DEI ditunjukkan pada Gambar 3. Gambar 3 menunjukkan interface aplikasi DEI yang akan menampilkan data dari Arduino. Data yang dikirim berupa hasil pembacaan sensor yang sudah dikonversi ke satuan MMI serta nilai maksimum gempa. Data yang diterima disimpan pada tabel database pada bagian bawah aplikasi. Data tersebut dapat disimpan dalam format .xlxs atau copy paste dari tabel. Nilai maksimum akan tampil saat ketiga sensor menerima getaran. 


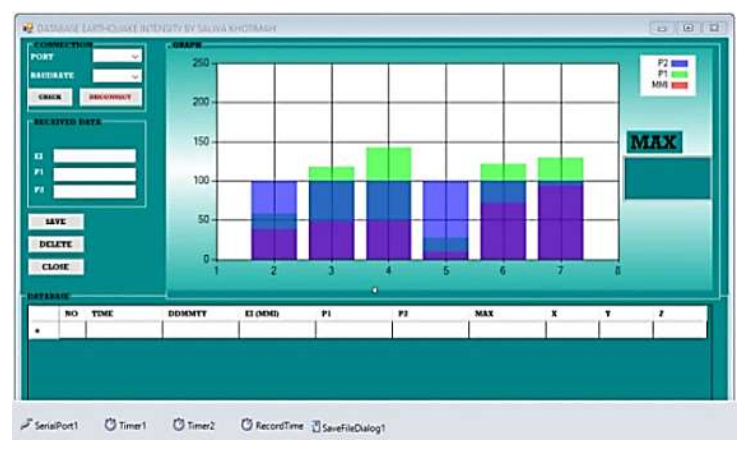

Gambar 3. Interface Aplikasi DEI

\subsection{Diagram Alir Sistem}

Diagram alir sistem seismograf digital ditunjukkan pada Gambar 4. Gambar 4 menunjukkan alur pemrograman yang akan dilakukan. Inisialisasi sensor bertujuan mengenalkan anatara pin-pin yang digunakan pada board mikrokontroller Arduino dengan software pemrograman Arduino agar hardware yang terhubung dikenali oleh Arduino. Selanjutnya bila inisialisasi telah dilakukan, maka sensor dapat mendeteksi getaran yang terjadi disekitarnya. Data yang diterima oleh Arduino ditampilkan pada aplikasi DEI serta LCD. Data yang diperoleh alat Eathquake Intensity meter ini disimpan pada database aplikasi DEI dan SDcard. Earthquake Intensity Meter akan bekerja lebih optimal dengan jaringan sistem telemetri yang baik (Lasala, 2015).

Bila ketiga sensor yakni, MPU6050 dan 2 buah sensor piezoelektrik mendeteksi getaran, maka Arduino mendefinisikannya sebagai gempa. Bila belum memenuhi kondisi tersebut, maka arduino tidak akan mendefinisikannya sebagai gempa. Nilai akselerasi yang terdeteksi oleh sensor MPU6050 dan nilai ADC dari kedua sensor piezoelektrik diolah sedemikian rupa untuk mendapatkan keluaran berupa MMI.
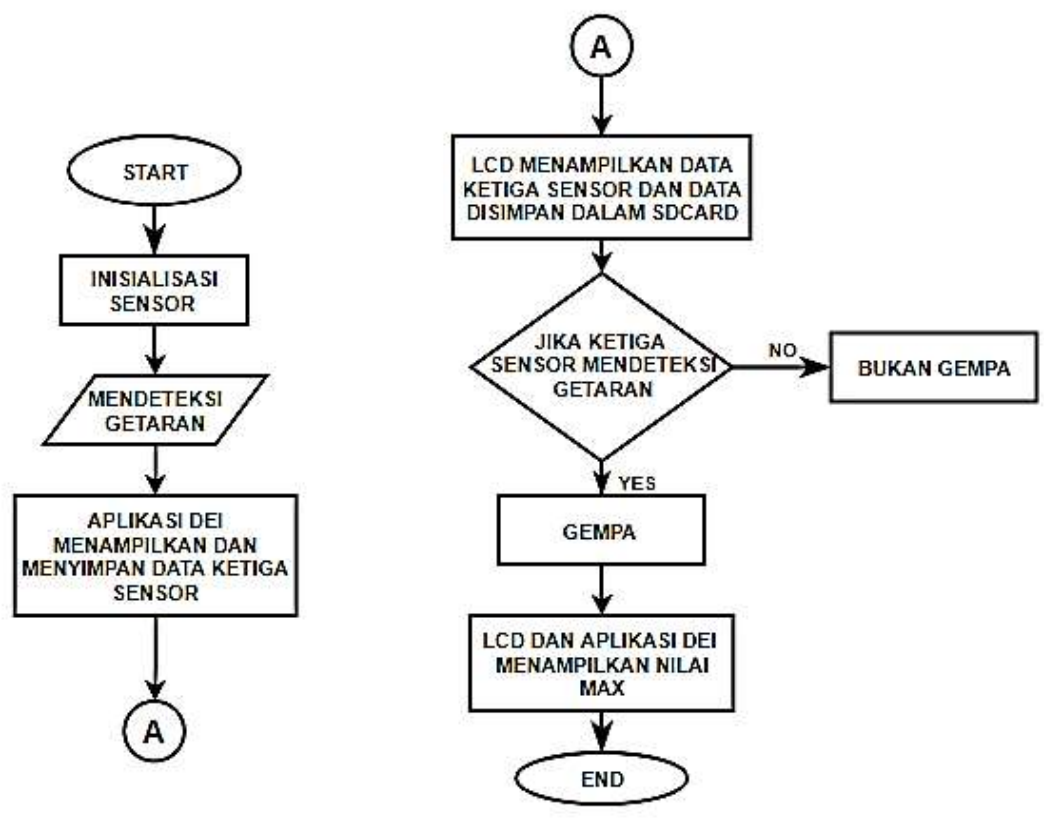

Gambar 4. Diagram Alir Seismograf (Earthquake Intensity Meter) 


\subsection{Pengujian dan Pengambilan Data}

Pengujian dan Pengambilan Data alat yang dirancang dilakukan secara eksperimental dengan melibatkan Stasiun Geofisika kelas III BMKG Kepahiang - Bengkulu sebagai mitra. Tujuannya menyesuaikan hasil pembacaan alat yang dirancang dengan alat yang digunakan oleh BMKG. Tahapan pengujian dan pengambilan data yang dilakukan sebagai berikut :

1. Membandingkan sensor akselerometer pada aplikasi Vibrometer smartphone dengan Intensity meter P-alert (pendeteksi gempa bumi dengan skala MMI) pada Stasiun Geofisika kelas III BMKG Kepahiang Bengkulu.

2. Melakukan kalibrasi sensor akselerometer yang digunakan pada rancangan alat Earthquake Intensity meter dengan aplikasi Vibrometer pada smartphone yang telah terkalibrasi. Tujuannya adalah untuk mengetahui sensitivitas sensor dalam mendeteksi getaran yang sangat kecil yang sesuai dengan karakteristik getaran gempa bumi.

3. Menguji performa sistem secara keseluruhan pada aplikasi DEI dan display LCD serta data logger di SDcard.

\section{HASIL DAN PEMBAHASAN}

Modul deteksi gempa yang digunakan BMKG ditunjukkan pada gambar 5. Alat ini dilengkapi rekaman data atau seismogram serta sistem perhitungan waktu pencatatan getaran tanah hasil rambatan gelombang gempa bumi. Seismometer modern menggunakan sistem elektronik. Pada beberapa sistem, massa dijaga sampai hampir tidak bergerak relatif terhadap kerangka alat dengan sebuah komponen elektronik negative feedback loop (putaran umpan balik negatif). Gerakan relatif massa terhadap kerangka akan terukur, dan putaran umpan balik menggunakan gaya magnet (elektrostatis) untuk menjaga massa hampir tidak bergerak.

Tegangan yang diperlukan untuk menghasilkan gaya ini adalah output dari seismometer yang direkam secara digital. Pada sistem yang lain massa dibiarkan bergerak, dan gerakan ini menghasilkan sebuah tegangan listrik dalam kumparan yang dipasang pada massa dan bergerak melalui medan magnet dari sebuah magnet yang dipasang pada kerangka/dudukan. Seismometer modern bekerja secara elektronik, yang tidak lagi menggunakan pena dan drum, gerakan relatif antara beban dan rangka menghasilkan tegangan listrik yang direkam oleh sebuah komputer. Dengan memodifikasi susunan pegas, beban, dan rangka, seismometer dapat merekam gerakan pada berbagai arah. Seismometer juga merekam gerakan tanah yang disebabkan oleh berbagai jenis sumber getaran alami dan sumber getaran buatan manusia, seperti pohon tertiup angin, mobil dan truk di jalan raya, dan ombak lautan yang menghantam pantai.

Umumnya semua tipe sistem operasi seismograf dilengkapi oleh putaran gulungan koil yang terhubungkan dengan penguat listrik. Hal terpenting dalam sistem seismograf adalah dinamika pendulum, mekanis seismograf, putaran koil dalam jenis seismometer elektromagnet, dan seismometer arus balik (feed back). Seismograf terbaru menggunakan sensor akselerometer untuk mendeteksi getaran bumi dari 3 arah. Arah barat-timur direpresentasikan oleh sumbu $X$, arah utara-selatan oleh sumbu $Y$, dan arah atas-bawah oleh sumbu Z. 


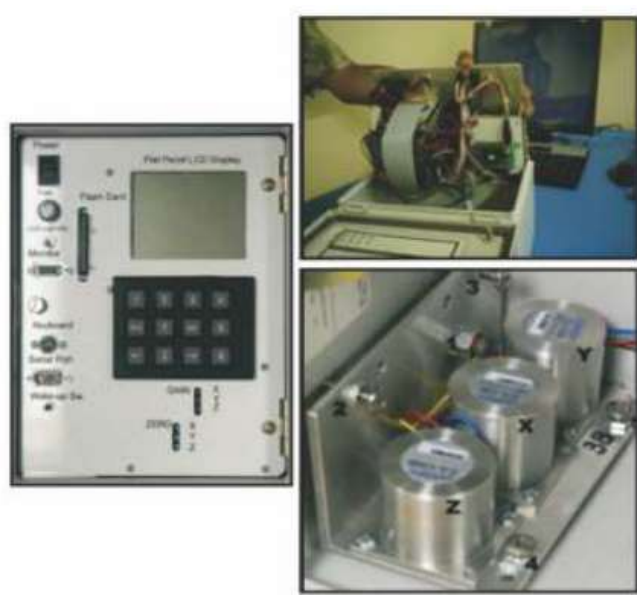

Gambar 5. Modul Gempa Milik BMKG

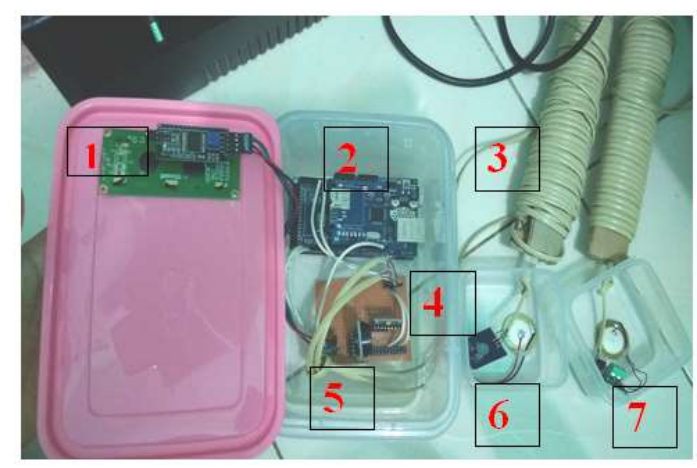

Gambar 6. Modul Gempa Yang Dirancang

Bentuk fisik hasil rancangan Modul Deteksi Gempa ditunjukkan pada Gambar 6. Keterangan Gambar 6 adalah sebagai berikut :

1. LCD

2. Arduino Mega 2560 dan SDcard shield

3. Kabel telepon sepanjang 10 meter

4. Sensor MPU6050
5. RTC DS3231

6. Sensor Piezoelektrik 1

7. Sensor Piezoelektrik 2

Kabel yang dipilih untuk menghubungkan sensor utama dengan kedua sensor piezoelektrik adalah kabel telepon (RJ11). Dipilihnya kebel tersebut karena penghantarnya tipis sehingga rugi-rugi daya pada penghantar yang panjang dapat diminimalkan. Sebelum dilakukan pengunggahan kode program, dilakukan terlebih dahulu pengukuran nilai tegangan pada ujung penghantar yang digunakan untuk memastikan apakah kabel ini dapat digunakan atau tidak. Hasil pengukuran tegangan yang didapatkan saat pengujian bernilai $4.984 \mathrm{~V}$. Hasil tegangan ini sudah cukup untuk memenuhi syarat dalam mengoperasikan sensor piezoelektrik. Hal ini menunjukkan bahwa panjangnya kabel tidak mempengaruhi besar tegangan yang sampai pada sensor dan kabel ini dapat diterapkan pada sistem pendeteksi gempa.

\subsection{Pengujian Sensor MPU6050}

Sensor MPU6050 merupakan sensor MEMS yang terdiri dari dua sensor didalamnya, yakni akselerometer dan giroskop. Sensor MPU6050 memiliki I2c address yang bernilai 0x68. Namun adrees ini akan digunakan untuk RTC. Karena itu digunakan address 0x69 dengan merubah nilainya pada file.h pada folder librarynya. Untuk menggunakan address tersebut, maka pin ADO harus dihubungkan dengan VCC atau memberi logika HIGH pada sensor. Bentuk pemasangannya ditunjukkan pada Gambar 7.

Sebelum dipasang pada sistem, dilakukan pengujian terlebih dahulu untuk melihat apakah sensor akselerometer atau giroskop cocok dalam mendeteksi gempa. Dalam hal ini digunakan library dari MPUlight yang berlisensi dan dibuat oleh MIT. Hasil pengujiannya sensor akselerometer ditunjukkan pada Gambar 7 dan hasil pengujian sensor giroskop ditunjukkan pada Gambar 9. 


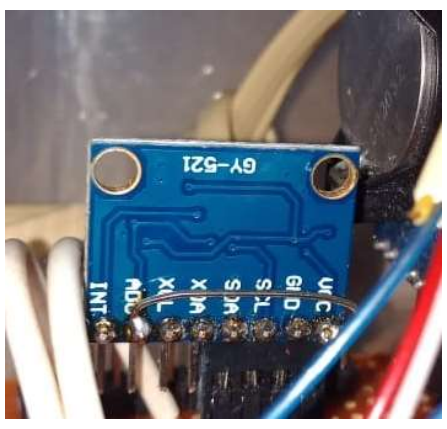

\section{Gambar 7. Pemasangan Sensor MPU6050}

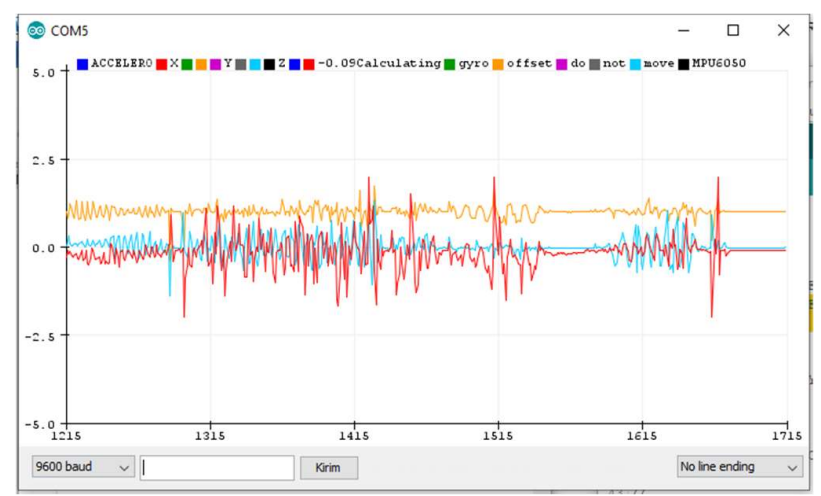

Gambar 8. Hasil Pengujian Sensor Akselerometer

Gambar 8 menunjukkan bahwa sumbu X,Y,dan Z secara berturut-turut divisualisasikan dengan warna merah, kuning, dan biru. Kelemahan dari sensor akselerometer ini adalah saat kondisi diam/tidak mendeteksi getaran, pembacaan percepatan pada sumbu $X$ tidak menunjukkan angka nol. Selain itu, rentang pembacaan sensor juga kecil, hanya bernilai $\pm 2 \mathrm{~g}$ saja. Setelah dilihat pada library, tenyata memang digunakan range $\pm 2 \mathrm{~g}$ saja, ditunjukkan pada Gambar 9.

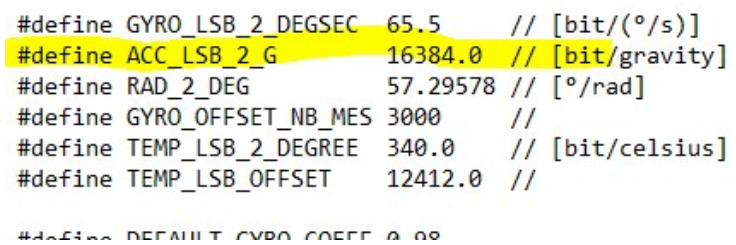

\section{Gambar 9. Penggunaan Range 2G pada Library}

Penggunaan range akselerometer ditunjukkan pada Gambar 8 yang ditandai dengan warna kuning. Sempitnya rentang pembacaan sensor akselerometer ini akan menyebabkan proses kalibrasi akan menjadi sulit.

Gambar 10 menunjukkan bahwa hasil pembacaan sensor utuk sumbu $X, Y$, dan Z secara berturut-turut divisualisasikan dengan warna kuning, biru muda, dan merah. Rentang nilai pembacaan sensor yang dihasilkan lebih lebar dari sensor akselerometer. Dengan hasil pengujian ini, maka dipilihlah sensor giroskop untuk digunakan pada sistem pendeteksi gempa yang dirancang. 


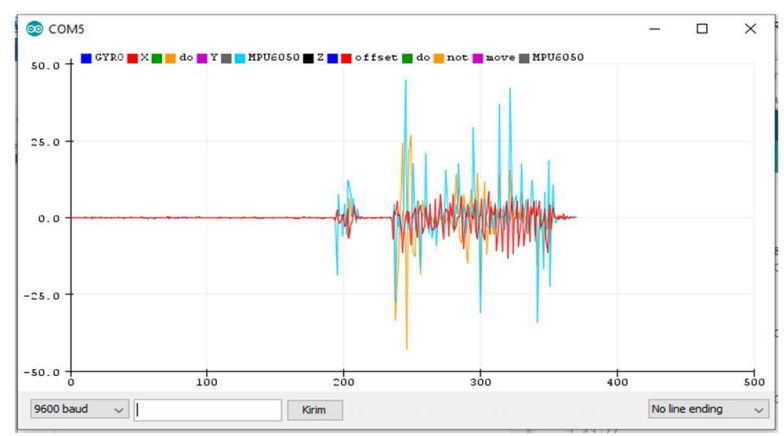

Gambar 10. Hasil Pengujian Sensor Giroskop

\subsection{Pengujian Sensor Piezoelektrik}

Sensor pendeteksi getaran yang digunakan selain sensor MPU6050 adalah sensor piezolektrik. Hasil pengujian sensor piezoelektrik saat diberikan getaran ditunjukkan pada Gambar 11.

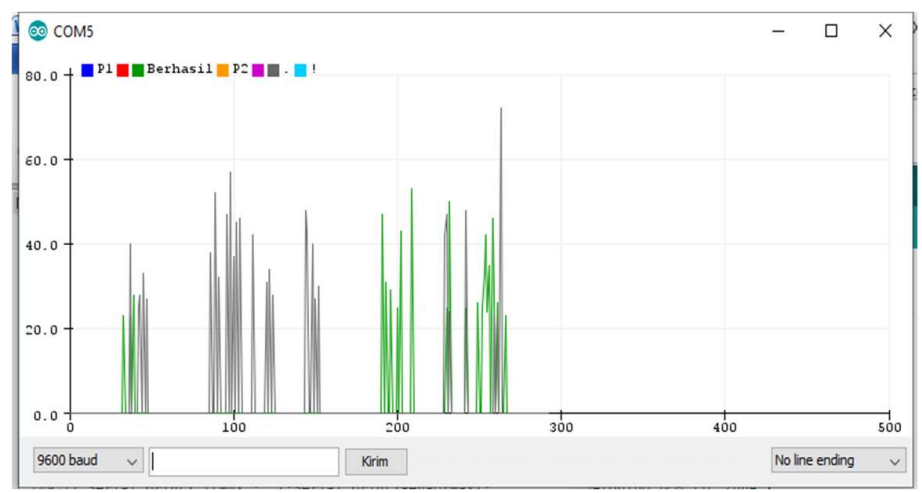

Gambar 11. Hasil Pengujian Sensor Piezoelektrik

Gambar 11 menunjukkan hasil pembacaan sensor piezoelektrik. Sensor piezo memiliki 3 pin, yakni VCC, GND, dan data. Saat menerima getaran pin data sensor piezoelektrik akan mengeluarkan tegangan yang berbanding lurus dengan seberapa kencang getaran yang diterimanya. Nilai yang ditampilkan pada grafik di atas adalah hasil konversi nilai tegangan 0 hingga $5 \mathrm{~V}$ menjadi nilai digital yang bernilai 0 hingga 1023 . Nilai 1023 diperoleh dari $2^{8}-1$ karena Arduino menggunakan ADC 8 bit.

\subsection{Perbandingan Hasil Ukur Aplikasi Vibrometer Smartphone dengan Intensity Meter P-A/ert}

Vibrometer adalah aplikasi android yang mengolah data dari sensor akselerometer pada smartphone android untuk mendeteksi getaran gempa bumi. Aplikasi ini digunakan sebagai pembanding data dari sistem pendeteksi gempa yang dikembangkan. Sebelum digunakan sebagai pembanding, aplikasi ini terlebih dahulu dibandingkan hasil pembacaannya dengan Intensity Meter $P$-alert milik Stasiun Geofisika Kelas III di Kepahiyang Bengkulu. 
Tabel 1. Perbandingan Hasil Vibrometer Dengan Intensity Meter Pada Nilai 3 MMI

\begin{tabular}{|c|c|c|c|}
\hline $\begin{array}{c}\text { Percobaan } \\
\text { ke- }\end{array}$ & $\begin{array}{c}\text { Aplikasi } \\
\text { Vibrometer (MMI) }\end{array}$ & $\begin{array}{c}\text { Intensity } \\
\text { Meter (MMI) }\end{array}$ & $\begin{array}{c}\text { Error } \\
\mathbf{( \% )}\end{array}$ \\
\hline 1. & 2,2 & 3 & 26,66 \\
\hline 2. & 2,3 & 3 & 16,66 \\
\hline 3. & 2,2 & 3 & 26,66 \\
\hline 4. & 2,4 & 3 & 20 \\
\hline 5. & 2,2 & 3 & 26,66 \\
\hline 6. & 2,4 & 3 & 16,66 \\
\hline 7. & 2,3 & 3 & 23,33 \\
\hline 8. & 2,5 & 3 & 16,66 \\
\hline 9. & 2,3 & 3 & 23,33 \\
\hline 10. & 2,6 & 3 & 13,33 \\
\hline \multicolumn{4}{|r}{ Rata-Rata Error } \\
\hline
\end{tabular}

Tabel 2. Perbandingan Hasil Vibrometer Dengan Intensity Meter Pada Nilai 4 MMI

\begin{tabular}{|c|c|c|c|}
\hline $\begin{array}{c}\text { Percobaan } \\
\text { ke- }\end{array}$ & $\begin{array}{c}\text { Aplikasi } \\
\text { Vibrometer (MMI) }\end{array}$ & $\begin{array}{c}\text { Intensity } \\
\text { Meter (MMI) }\end{array}$ & $\begin{array}{c}\text { Error } \\
(\%)\end{array}$ \\
\hline 1. & 3,4 & 4 & 15 \\
\hline 2. & 3,2 & 4 & 20 \\
\hline 3. & 3,6 & 4 & 10 \\
\hline 4. & 3,4 & 4 & 15 \\
\hline 5. & 4 & 4 & 0 \\
\hline 6. & 3,6 & 4 & 10 \\
\hline 7. & 3,4 & 4 & 15 \\
\hline 8. & 3,7 & 4 & 7,5 \\
\hline 9. & 3,5 & 4 & 12,5 \\
\hline 10. & 3,4 & 4 & 15 \\
\hline \multicolumn{3}{|c|}{ Rata-rata Error } & 12 \\
\hline
\end{tabular}

Tabel menunjukkan bahwa rata-rata error untuk nilai 3 MMI adalah 21\%. Sedangkan untuk nilai 4 MMI adalah 12\%. Dengan demikian maka error yang dihasilkan adalah:

$$
\text { Error }=\frac{21+1}{2}=16,5 \% \approx 17 \%
$$

\subsection{Kalibrasi Rancangan Alat Pendeteksi Gempa Dengan Aplikasi Vibrometer Smartphone}

Setelah diketahui tingkat akurasi aplikasi Vibrometer, selanjutnya dilakukan kalibrasi sensor pada rancangan pendeteksi gempa dengan aplikasi tersebut. Hasil perbandingan keduanya ditunjukkan pada Gambar 12.

Gambar 12 menunjukkan pada sumbu $X$ grafik merupakan hasil pembacaan sensor giroskop pada MPU6050 dan sumbu Y merupakan hasil pendeteksian pada aplikasi vibrometer dengan skala MMI. Dari grafik dihasilkan persamaan polinomial orde 3. Persamaan ini kemudian digunakan untuk menentukan besaran intensitas gempa pada rancangan alat yang akan dibuat. 


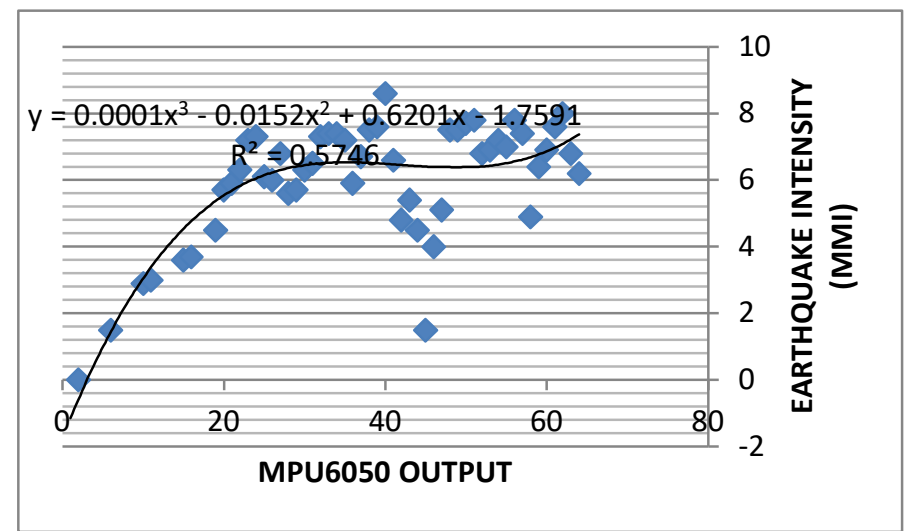

Gambar 12. Perbandingan Hasil Pembacaan Sensor MPU6050 dan Aplikasi Vibrometer

$$
y=0,0001 x^{3}-0,0152 x^{2}+0,6201 x-1,7591
$$

Untuk mendapatkan nilai yang setara dengan aplikasi vibrometer (y), maka hasil pendeteksian sensor giroskop MPU6050 (x) dikalikan dengan nilai yang terdapat pada Persamaan 1. Hasil pendeteksian rancangan alat Earthquake Intensity meter ditunjukkan pada Tabel 3.

Tabel 3. Perbandingan Vibrometer Dengan Rancangan Alat Earthquake Intensity Meter

\begin{tabular}{|c|c|c|c|}
\hline \multirow[b]{2}{*}{ No } & \multicolumn{3}{|c|}{ VM vs MPU6050 } \\
\hline & VM (MMI) & $\begin{array}{c}\text { MPU6050 } \\
\text { (MMI) }\end{array}$ & $\begin{array}{c}\text { ERROR } \\
(\%)\end{array}$ \\
\hline 1 & 4,4 & 4 & 10,00 \\
\hline 2 & 5,3 & 6 & 11,66 \\
\hline 3 & 4,5 & 4 & 12,50 \\
\hline 4 & 4,7 & 5 & 6,00 \\
\hline 5 & 4,7 & 4 & 17,50 \\
\hline 6 & 4,9 & 5 & 2,00 \\
\hline 7 & 5,8 & 7 & 17,14 \\
\hline 8 & 5,2 & 6 & 13,33 \\
\hline 9 & 5,3 & 5 & 6,00 \\
\hline 10 & 5,2 & 5 & 4,00 \\
\hline 11 & 5,3 & 7 & 24,28 \\
\hline 12 & 5,4 & 6 & 10,00 \\
\hline 13 & 5,5 & 7 & 21,42 \\
\hline 14 & 6,2 & 8 & 22,5 \\
\hline 15 & 5,7 & 7 & 18,57 \\
\hline 16 & 5,8 & 7 & 17,14 \\
\hline 17 & 5,8 & 7 & 17,14 \\
\hline 18 & 6,1 & 6 & 1,66 \\
\hline 19 & 6,1 & 8 & 23,75 \\
\hline 20 & 6,3 & 7 & 10,00 \\
\hline 21 & 6,4 & 7 & 8,57 \\
\hline 22 & 6,9 & 7 & 1,42 \\
\hline 23 & 7 & 7 & 0 \\
\hline 24 & 7,5 & 8 & 6,25 \\
\hline 25 & 7,7 & 7 & 10,00 \\
\hline Max Error & \multicolumn{3}{|c|}{24,28} \\
\hline Rata-rata & \multicolumn{3}{|c|}{11,17} \\
\hline
\end{tabular}

\subsection{Pengujian RTC}


Sistem pendeteksi gempa yang akan dirancang dilengkapi dengan fasilitas penyimpanan data. Dalam menyimpan data diperlukan suatu alat yang mampu untuk mencatatkan waktu secara realtime yaitu RTC Ds3231. Hasil pengujian RTC ditunjukkan pada Gambar 13.

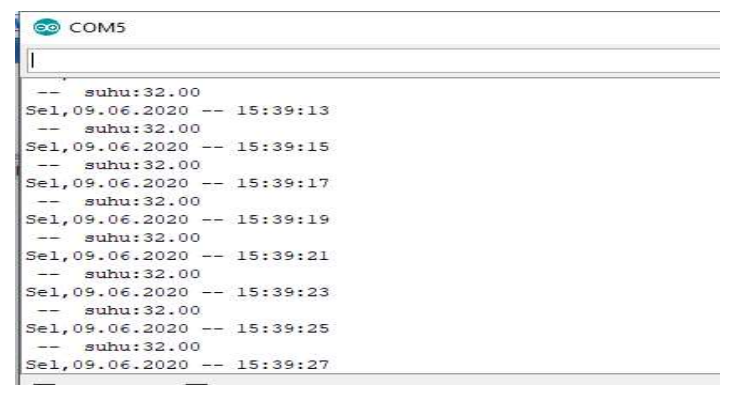

\section{Gambar 13. Hasil Pengujian RTC}

\subsection{Pengujian Secara Keseluruhan Pada Lcd}

Hasil pengujian sensor MPU6050 dan kedua sensor piezoelektrik diatur sedemikian rupa dengan logika AND dalam menentukan apakah terjadi gempa atau tidak. Tampilan alat ditunjukkan pada Gambar 14.

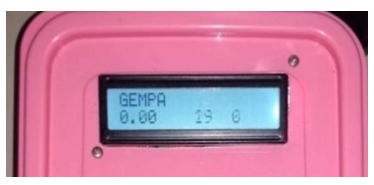

(a)

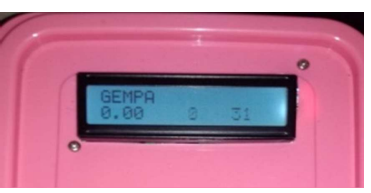

(b)

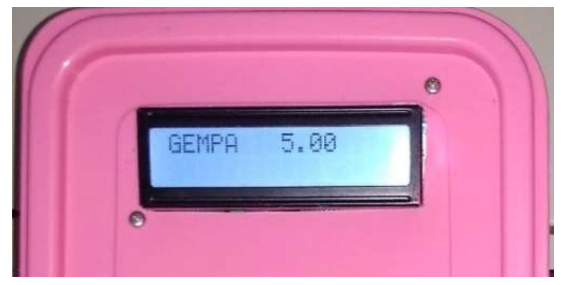

(c)

\section{Gambar 14. Tampilan LCD}

Gambar 14 menunjukkan tampilan LCD saat sensor mendeteksi getaran. Gambar 14 (a) menunjukkan saat hanya sensor P1 yang mendeteksi getaran. Gambar 14 (b) menunjukkan saat hanya sensor P2 mendeteksi getaran. Saat salah satu sensor mendeteksi getaran, maka pada baris pertama LCD hanya menampilkan tulisan "GEMPA". Gambar 14 (c) menunjukkan saat sensor MPU6050, P1 dan P2 mendeteksi getaran secara bersamaan, maka LCD akan menampilkan nilai intensitas gempa dalam skala MMI.

\subsection{Pengujian Sistem Secara Keseluruhan pada Aplikasi DEI (Database Earthquake Intensity)}

Hasil pendeteksian rancangan alat Earthquake Intensity meter ditampilkan dan disimpan pada aplikasi DEI (Database Earthquake Intensity) yang dirancang dengan Visual Basic 2010. Tampilan aplikasi DEI ditunjukkan pada Gambar 14. 


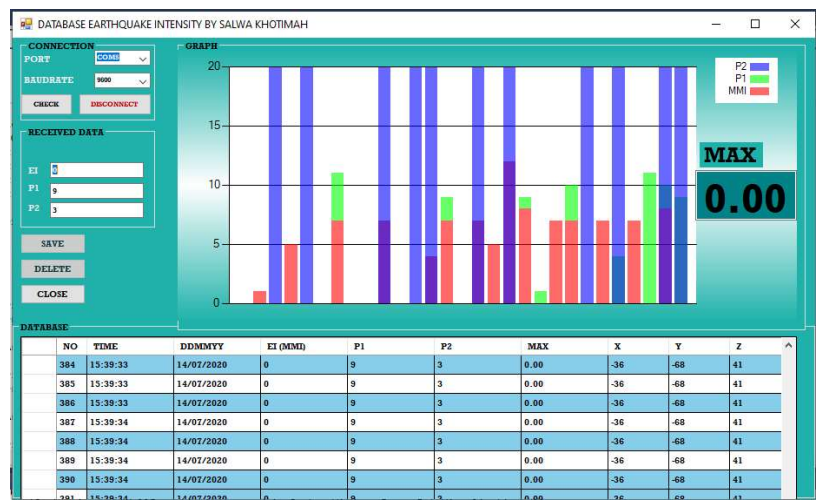

Gambar 15.Tampilan Aplikasi DEI

Gambar 15 menunjukkan tampilan data pengukuran sensor, visualisasi grafik, nilai maksimal, serta sistem datalogging. Data yang disajikan pada data grid view aplikasi dapat disimpan dengan format .xIxs. Data yang disimpan pada aplikasi DEI diantaranya hasil pendeteksian sensor giroskop pada MPU6050 yang telah dikonversi ke skala MMI, pendeteksian kedua sensor piezoelektrik, dan data mentah tiga aksis pendeteksian sensor giroskop (untuk mengetahui arah getaran yang terjadi). Kecepatan transfer data aplikasi ini setara dengan kecepatan saat Arduino menampilkan data melalui serial monitor. Nilai maksimum akan ditampilkan saat hasil pembacaan sensor memenuhi Persamaan 2.

$$
\mathrm{Z}=\operatorname{if}(\mathrm{mmi}>0 \& \& \mathrm{Aa}>0 \& \& \mathrm{Bb}>0)
$$

dimana : $\quad \mathrm{mmi}=$ output sensor MPU6050 yang telah diolah ke dalam range MMI

$\mathrm{Aa}=$ output sensor piezoelektrik 1

$\mathrm{Bb}=$ output sensor piezoelektrik 2

Berdasarkan persamaan 2, dalam hal ini nilai maksimum selain berfungsi untuk menampilkan nilai maksimun saja, juga berfungsi dalam penentuan gempa atau bukan gempa. Hasil pengujian sistem keseluruhan pada aplikasi DEI ditunjukkan pada Gambar 16. Gambar 16 merupakan hasil dari pembacaan data dari rancangan alat earthquake intensity meter. Dalam satu detik sistem melakukan 9-10 kali pencuplikan data. Gambar 16 juga menunjukkan bahwa saat ketiga sensor digetarkan secara bersamaan, terdapat selisih waktu dari masing-masing sensor dalam mendeteksi getaran. Hal ini menyebabkan terganggunya sistem dalam menentukan gempa atau tidak gempa. Selain itu, perbedaan tingkat sensitifitas sensor juga sangat mempengaruhi sistem yang dibuat. Dimana sensor MPU6050 lebih handal dalam mendeteksi getaran mulai yang terkecil hingga yang besar. Berbeda dengan sensor piezoelektrik yang kurang sensitif untuk mendeteksi getaran yang kecil.

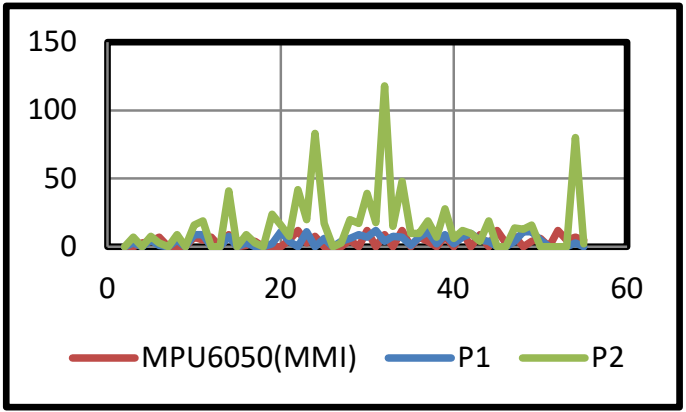

Gambar 16. Data yang Diperoleh dari Aplikasi DEI 
Dapat dilihat bahwa dari 53 kali geratan yang terdeteksi, hanya beberapa kali saja ketiga sensor mendeteksi getaran dalam waktu yang sama. Saat sensor piezo mendeteksi getaran, sedangkan MPU6050 tidak mendeteksi getaran. Begitu juga sebaliknya, saat sensor MPU6050 mendeteksi getaran, sedangkan sensor piezo tidak mendeteksi getaran. Tingkat keberhasilan sistem dalam menentukan gempa atau tidak gempa adalah (dihitung berdasarkan kolom MAX berwarna kuning) :

$$
\text { Keberhasilan : } \frac{17}{53} \times 100 \%=32 \%
$$

Perbedaan waktu pencuplikan masing-masing sensor bukan masalah yang begitu berarti, karena hal tersebut terjadi dalam waktu yang sangat cepat, yakni 1/10 detik. Sehingga sistem ini tetap dapat digunakan dalam monitoring gempa. Dengan catatan bahwa dalam menganalisa data gempa tidak dapat hanya mengandalkan nilai maksimum, melainkan harus mengamati pembacaan ketiga sensor dalam periode waktu tertentu sebelum dan sesudah tercatatnya nilai maksimum pada sistem.

\section{KESIMPULAN}

Aplikasi Vibrometer yang digunakan sebagai media kalibrasi, memiliki selisih $17 \%$ dengan intensity meter yang terpasang pada Stasiun Geofisika kelas III BMKG Kepahiang Bengkulu. Hal ini menjadi acuan dalam mengkalibrasi modul deteksi gempa yang dirancang. Dalam rancangan modul deteksi gempa, akurasi sensor MPU6050 memiliki selisih 11,17\% dengan aplikasi Vibrometer. Di sisi lain kombinasi sensor MPU6050 dan 2 sensor piezoelektrik mampu digunakan untuk membedakan getaran gempa dan bukan gempa dengan tingkat keberhasilan 32\%. Selanjutnya kedepan untuk meningkatkan keberhasilan modul, rancangan sistem pendeteksi gempa bisa dilakukan menggunakan 3 sensor. Hal ini untuk meningkatkan keberhasilan sistem dalam mendefinisikan gempa atau bukan gempa

\section{UCAPAN TERIMA KASIH}

Ucapan terima kasih disampaikan kepada Universitas Bengkulu selaku pemberi dana pada skema PNPB UNIB Tahun 2019 Nomor Kontrak : 2174/UN30.15/LT/2019. Semoga dapat bermanfaat untuk semua pembaca.

\section{DAFTAR RUJUKAN}

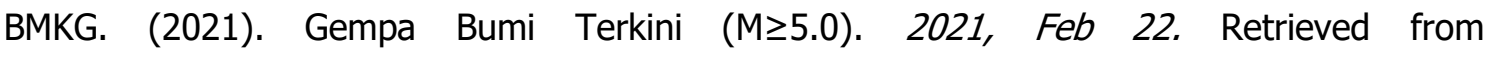
http://www.bmkg.go.id/gempabumi/gempabumi-terkini.bmkg

Crisnapati, P. N., dkk. (2019). Earthquake Damage Intensity Scaling System based on Raspberry Pi and Arduino Uno. 6th Int. Conf. Cyber IT Serv. Manag. CITSM 2018, no. Citsm, (pp. 1-4).

Dadafshar, M. (2014). Accelerometer And Gyroscopes Sensors : Operation, Sensing, And Applications. Retrieved from https://pdfserv.maximintegrated.com/en/an/AN5830.pdf

Firman, B. (2016). Implementasi Sensor IMU MPU6050 Berbasis Serial I2C pada SelfBalancing Robot. J. Teknol. Technoscientia, 9(1), 18-24. 
Fu, J., dkk. (2019). Performance Evaluation of Low-Cost Seismic Sensors for Dense Earthquake Early Warning : 2018-2019 Field Testing in Southwest China. Sensors, $19,1999$.

Hoque, R., dkk. (2016). Earthquake monitoring and warning system. Proc. 2015 3rd Int. Conf. Adv. Electr. Eng. ICAEE 2015, (pp. 109-112).

Lasala, M., dkk. (2015). Establishment of Earthquake Intensity Meter Network in the Philippines. Journal of Disaster Research, 10(1), 43-50.

Naito, S., dkk. (2013). Development and Testing of a Mobile Application for Recording and Analyzing Seismic Data. JDR, 8(5), 990-1000.

Novianta, M. A. (2014). Wireless Earthquakes Feature Monitoring Based on Acceleration and Magnetic Measurements Using MEMS. Sensor, 189-192.

Peng, C., dkk. (2017). A New Type of Tri-Axial Accelerometers with High Dynamic Range MEMS for Earthquake Early Warning. Computers \& Geosciences, 100, 179-187.

Priyana, Y., dkk. (2017). Development of Earthquake Early Warning System using ADXL335 Accelerometer. Proc. Int. Conf. Satell. Technol., (pp. 81-85).

Putra, W. (2019). BMKG Pasang 194 Seismograf di Indonesia. 2019, Oct 25. Retrieved from https://news.detik.com/berita-jawa-barat/d-4759593/bmkg-pasang-194-seismografdi-indonesia.

Rahman, M., dkk. (2016). Implementation of ICT and Wireless Sensor Networks for Earthquake Alert and Disaster Management in Earthquake Prone Areas. International Conference on Computational Modeling and Security (CMS 2016), (pp. 92 - 99).

Wang. (2016). A Low-cost Design of Earthquake Detector with Rescue Message Deliver using Mobile Device. Proceedings of Engineering and Technology Innovation, (pp. 04 - 05).

Won, J., dkk. (2020). BLESeis : Low-Cost IoT Sensor for Smart Earthquake Detection and Notification. Sensors, 20(2963). 